dr inż. Leszek Wittenbeck

mgr in.s. Szymon Milecki

dr inż. Grażyna Barna

Instytut Pojazdów Szynowych „,TABOR”

\title{
Platforma Stewarta-Gougha jako uklad ruchu symulatora jazdy pojazdu szynowego
}

\begin{abstract}
Artykut przedstawia koncepcje uktadu ruchu symulatora jazdy pojazdy szynowego. Najbardziej zaawansowane symulatory posiadaja w petni wyposazona kabine, 360stopniowy system wizyjny oraz ruchoma platforme o 6-ciu stopniach swobody, która może imitować warunki jazdy. Układ ruchu jest platforma Stewarta-Gougha, która sktada sie z ruchomej platformy i nieruchomej podstawy połaczonych ze soba za pomoca przegubów i sześciu nóg o zmiennej dtugości (siłowników). Zadany ruch platformy wymaga skoordynowanego ruchu wszystkich sześciu siłowników zależnego od pozycji i orientacji platformy. Geometryczne relacje pomiędzy pozycja i orientacja platformy, a dtugościami sześciu nóg sq wyliczane z kinematyki odwrotnej. W celu wyznaczenia wymaganych sit $w$ siłownikach dla zadanego ruchu platformy wyprowadzono równania dynamiki odwrotnej przy pomocy formalizmu Newtona-Eulera. Równania kinematyki $i$ dynamiki odwrotnej moga być użyte $w$ opracowaniu sposobów sterowania platforma w czasie rzeczywistym. Zaproponowano koncepcję sterownika bazujacego na karcie analogowo-cyfrowej oraz komputerze $w$ celu weryfikacji algorytmu sterowania.
\end{abstract}

\section{Wstęp}

Symulatory jazdy maja szerokie spektrum zastosowań. Są używane od kilku dekad w badaniach naukowych, przemyśle motoryzacyjnym i wojskowym. Pierwsze prace nad symulatorami sięgają lat pięćdziesiątych minionego wieku. Początkowo były zaprojektowane, aby pomóc kierowcą trenować umiejętności prowadzenia pojazdu. Później stosowano je do profesjonalnego szkolenia kierowców pojazdów specjalnych przeznaczonych do jazdy w specyficznych warunkach. Obecnie symulatory wysoce odwzorowujące rzeczywistość (zaawansowane) są używane jako urządzenia do szkolenia kierowców i trenowania zachowań w zadanych warunkach. Stosuje się je również do badania interakcji kierowca-pojazd w celu rozwiązania wielu problemów konstrukcyjnych pulpitów sterowniczych, głównie ergonomicznych. Wirtualna rzeczywistość symulatora jest również dobrym miejscem zdobywania informacji na temat reakcji i odruchowych zachowań użytkowników.

Symulatory jazdy różnią się poziomami odwzorowania rzeczywistości. Można je podzielić na trzy grupy: wysoko, średnio i nisko oddające rzeczywistość. Ze względu na wysokie wymagania techniczne i głównie brak seryjnej produkcji zaawansowane symulatory jazdy są bardzo kosztowne. Jednak z drugiej strony bardzo realnie oddaja warunki jazdy dzięki pełnowymiarowej kabinie i sześciu stopniom swobody. Symulatory nisko odwzorowujące rzeczywistość mają prostą budowę. Są nieruchome i wymagaja jedynie osobistego komputera lub graficznej stacji roboczej, monitora, podstawowego wyposażenia kabiny (np. kierownicy, nastawników, pedałów). Zwykłe zaliczają się do nich gry symulujące obsługę pojazdów. Pomiędzy tymi dwoma typami symulatorów występuje typ pośredni, który jest nieruchomy, lecz posiada $\mathrm{w}$ pełni wyposażoną kabinę. Ten typ symulatorów pełni funkcje trenażerów umożliwiających trening jakiejś sprawności (np. prowadzenia pojazdu). Na rys. 1 pokazano klasyfikację symulatorów.
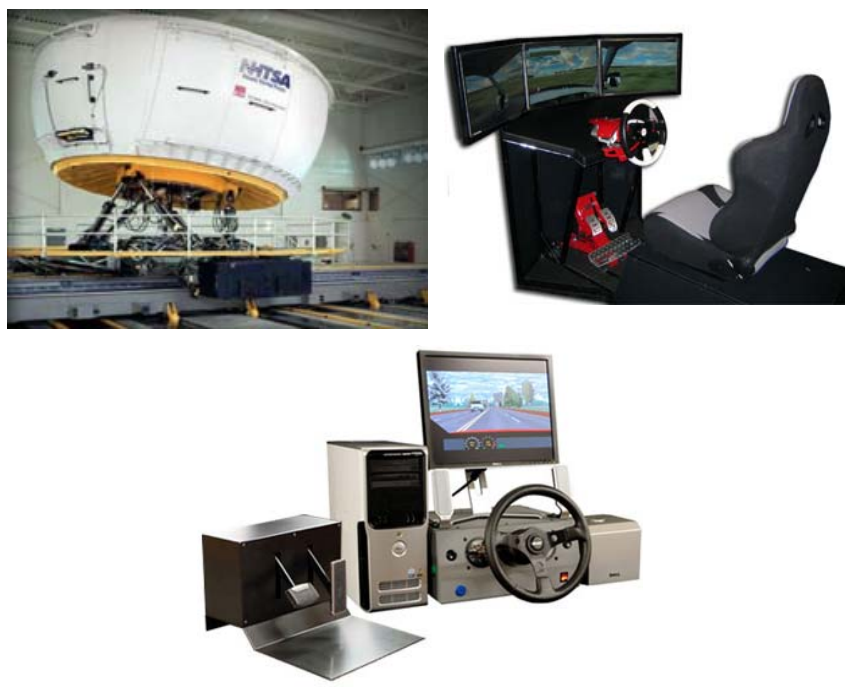

Rys.1. Klasyfikacja symulatorów

Projektowanie zaawansowanego symulatora jazdy można podzielić na trzy części: zaprojektowanie i stworzenie ruchomej platformy, zaprojektowanie 
systemu sterowania, symulacji-wizualizacji, połączenie powyższych elementów w integralną całość wraz $\mathrm{z}$ walidacją.

\section{Ruchoma platforma}

Ruchoma platforma zaprojektowana jest jako platforma Stewarta-Gougha. Wybrano platformę Stewarta-Gougha ponieważ jest ona równoległym manipulatorem o 6 stopniach swobody. Górna platforma połączona jest $\mathrm{z}$ nieruchomą podstawą przy pomocy sześciu siłowników. Pozwala to na uzyskanie lepszej dokładności ruchów oraz możliwość przeniesienia dużych obciążeń. Model ruchomej platformy pokazano na rys. 2. Pozycja górnej platformy jest zdefiniowana przez współrzędne przegubów sześciu siłowników. Miejsca zamocowania przegubów tworzą na górnej platformie nieregularny sześciokąt opisany na okręgu. Wierzchołki tego sześciokąta opisane są przez sześć wektorów związanych z lokalnym układem współrzędnych przyjętym na górnej platformie. Środek tego układu pokrywa się ze środkiem sześciokąta. Podstawa zdefiniowana jest w globalnym układzie współrzędnych o środku w środku podstawy. Podobnie, jak w przypadku górnej platformy, podstawa ma kształt nieregularnego sześciokąta opisanego na okręgu.

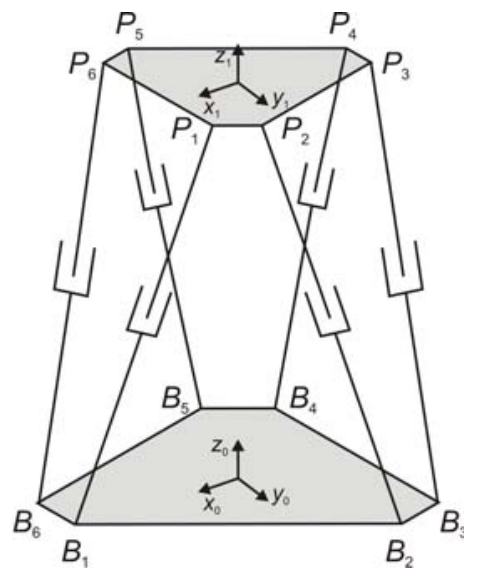

$$
R_{0}^{1}=\left[\begin{array}{ccc}
\cos (\psi) \cos (\theta) & -\sin (\psi) \cos (\phi)+\cos (\psi) \sin (\theta) \sin (\phi) & \sin (\psi) \sin (\phi)+\cos (\psi) \sin (\theta) \cos (\phi) \\
\sin (\psi) \cos (\theta) & \cos (\psi) \cos (\phi)+\sin (\psi) \sin (\theta) \sin (\phi) & -\cos (\psi) \sin (\phi)+\sin (\psi) \sin (\theta) \cos (\phi) \\
-\sin (\theta) & \cos (\theta) \sin (\phi) & \cos (\theta) \cos (\phi)
\end{array}\right]
$$

Rys.2. Model platformy Stewarta-Gougha

Oś $x_{1}$ jest prostopadła do linii łączącej wierzchołki $P_{1}$ i $P_{6}$. Kąt pomiędzy wierzchołkami $P_{1}$ i $P_{2}$ jest oznaczony przez $\alpha_{P}$. Kąty pomiędzy wierzchołkami $P_{1}$ i $P_{3}$ oraz $P_{3}$ i $P_{5}$ wynoszą $120^{\circ}$. Podobnie dla nieruchomej podstawy oś $x_{0}$ jest prostopadła do linii łączącej wierzchołki $B_{1}$ i $B_{6}$. Kąt pomiędzy wierzchołkami $B_{1}$ i $B_{2}$ jest oznaczony przez $\alpha_{B}$. Kąty pomiędzy wierzchołkami $B_{1}$ i $B_{3}$ oraz $B_{3}$ i $B_{5}$ wynoszą $120^{\circ}$. Ponadto kąt pomiędzy wektorem wodzącym wierzchołka $P_{1}$ a osią $x_{1}$ oznaczono jako $\lambda_{i}$, a kąt pomiędzy wektorem wodzącym wierzchołka $B_{1}$ a osią $x_{0}$ jako $\gamma_{i}$. Mamy dla wierzchołków o indeksie $\mathrm{i}=1,3,5$

$$
\gamma_{i}=60^{\circ} \cdot i-\frac{\alpha_{B}}{2}, \quad \lambda_{i}=60^{\circ} \cdot i-\frac{\alpha_{P}}{2},
$$

oraz dla $i=2,4,6$,

$$
\gamma_{i}=\gamma_{i-1}+\alpha_{B}, \quad \lambda_{i}=\lambda_{i-1}+\alpha_{P}
$$

Niech $R_{B}$ jest promieniem okręgu opisanego na nieruchomej podstawie, a $R_{P}$ promieniem okręu opisanego na ruchomej platformie. Wówczas wektor $\vec{p}_{i}^{(1)}$ opisujący pozycję przegubów na ruchomej platformie dla i-tego siłownika w układzie $0 x_{1} y_{1} z_{1}$ ma postać

$$
\vec{p}_{i}^{(1)}=\left[R_{P} \cos \left(\lambda_{i}\right), R_{P} \sin \left(\lambda_{i}\right), 0\right] .
$$

Natomiast wektor $\vec{b}_{i}$ opisujący pozycję przegubów na nieruchomej podstawie dla i-tego siłownika w układzie $0 x_{0} y_{0} z_{0}$ ma postać

$$
\vec{b}_{i}=\left[R_{B} \cos \left(\gamma_{i}\right), R_{B} \sin \left(\gamma_{i}\right), 0\right] .
$$

Położenie lokalnego układu odniesienia $0 x_{1} y_{1} z_{1}$ jest opisane przez wektor $\vec{t}$, a orientacja ruchomego układu $0 x_{1} y_{1} z_{1} \quad$ względem ustalonego układu $0 x_{0} y_{0} z_{0}$ jest dana przez trzy katy (RPY) $\phi, \theta, \psi$. Dla zadanych kątów obrotu, nachylenia i odchylenia, macierz kosinusów kierunkowych opisująca orientację układu $0 x_{1} y_{1} z_{1}$ względem $0 x_{0} y_{0} z_{0}$, dana jest następującym wzorem.

\section{Prędkość kątowa}

Obrót z układu współrzędnych $0 x_{0} y_{0} z_{0}$ do układu współrzędnych $0 x_{1} y_{1} z_{1}$ opisany jest przez kąty

$$
R_{0}^{a}=R_{z, \psi}, \quad R_{a}^{b}=R_{y^{\prime}, \theta}, \quad R_{a}^{1}=R_{x^{\prime \prime}, \phi} .
$$

Prędkości kątowe opisane są przez

$$
\vec{\omega}_{a 0}^{0}=[0,0, \dot{\psi}]^{T}, \quad \vec{\omega}_{b a}^{a}=[0, \dot{\theta}, 0]^{T}, \quad \vec{\omega}_{1 b}^{b}=[\dot{\phi}, 0,0]^{T} .
$$

Wówczas

$\vec{\omega}_{10}^{0}=\vec{\omega}_{a 0}^{0}+R_{0}^{a} \vec{\omega}_{b a}^{a}+R_{0}^{b} \vec{\omega}_{1 b}^{b}=\vec{\omega}_{a 0}^{0}+R_{0}^{a} \vec{\omega}_{b a}^{a}+R_{0}^{a} R_{a}^{b} \vec{\omega}_{1 b}^{b}$

Stąd otrzymujemy

$$
\vec{\omega}_{10}^{0}=\left[\begin{array}{ccc}
\cos (\psi) \cos (\theta) & -\sin (\psi) & 0 \\
\sin (\psi) \cos (\theta) & \cos (\psi) & 0 \\
-\sin (\theta) & 0 & 1
\end{array}\right] \cdot\left[\begin{array}{c}
\dot{\phi} \\
\dot{\theta} \\
\dot{\psi}
\end{array}\right]=E(\beta) \cdot \dot{\vec{\beta}}
$$

gdzie $\vec{\beta}=[\phi, \theta, \psi]^{T}$. 
Przyspieszenie kątowe

gdzie

$$
\vec{\varepsilon}=\dot{\vec{\omega}}=\dot{E}(\beta) \cdot \dot{\vec{\beta}}+E(\beta) \cdot \ddot{\vec{\beta}},
$$

$$
\dot{E}(\beta)=\left[\begin{array}{ccc}
-\dot{\psi} \sin (\psi) \cos (\theta)-\dot{\theta} \cos (\psi) \sin (\theta) & -\dot{\psi} \cos (\psi) & 0 \\
\dot{\psi} \cos (\psi) \cos (\theta)-\dot{\theta} \sin (\psi) \sin (\theta) & -\dot{\psi} \sin (\psi) & 0 \\
-\dot{\theta} \cos (\theta) & 0 & 0
\end{array}\right] .
$$

\section{Prędkość liniowa}

$$
\vec{v}=\dot{\vec{t}}
$$

\section{Przyspieszenie liniowe}

$$
\vec{a}=\dot{\vec{v}}=\ddot{\vec{t}} \text {. }
$$

\section{Kinematyka i dynamika silownika}

\subsection{Kinematyka i-tego siłownika}

Jeżeli wektor opisujący pozycję lokalnego układu odniesienia górnej platformy $\vec{t}$ oraz macierz obrotu $R_{0}^{1}$ są dane, to wektor opisujący pozycję i-tego siłownika o początku w wierzchołku $B_{i}$ i końcu w wierzchołku $P_{i}$ zdefiniowany jest jako

$$
\vec{S}_{i}=\vec{q}_{i}+\vec{t}-\vec{b}_{i},
$$

gdzie

$$
\vec{q}_{i}=R_{0}^{1} \vec{p}_{i}^{(1)} .
$$

Długość wektora $\vec{S}_{i}$ dana jest wzorem

$$
L_{i}=\left|\vec{S}_{i}\right|=\sqrt{\vec{S}_{i} \cdot \vec{S}_{i}}
$$

Wersor kierunkowy i-tego siłownika ma postać

$$
\vec{s}_{i}=\frac{\vec{S}_{i}}{L_{i}} .
$$

Wobec tego wektor opisujący pozycję i-tego siłownika można zapisać

$$
\vec{S}_{i}=L_{i} \vec{s}_{i}
$$

Długości wszystkich sześciu siłowników można zestawić w sześcioelementowy wektor $\vec{L}$

$$
\vec{L}=\left[L_{1}, L_{2}, \ldots, L_{6}\right]^{T}
$$

Prędkość wierzchołka $P_{i}$ jest pochodną względem czasu wektora $\vec{S}_{i}$, opisującego pozycję i-tego siłownika, i wyrażona przy pomocy prędkości kątowej $\vec{\omega}_{10}$ ruchomej platformy ma postać

$\dot{\vec{S}}_{i}=\dot{\vec{q}}_{i}+\dot{\vec{t}}=\dot{R}_{0}^{1} \vec{p}_{i}^{(1)}+R_{0}^{1} \dot{\vec{p}}_{i}+\vec{v}=S\left(\vec{\omega}_{10}\right) R_{0}^{1} \vec{p}_{i}^{(1)}+\vec{v}=S\left(\vec{\omega}_{10}\right) \vec{q}_{i}+\vec{v}=\vec{\omega}_{10} \times \vec{q}_{i}+\vec{v}$

Prędkość wysuwu i-tego siłownika dana są wzorem

$$
\dot{L}_{i}=\vec{s}_{i} \cdot \dot{\vec{S}}_{i}
$$

\section{Zatem}

$\dot{L}_{i}=\vec{s}_{i} \cdot \dot{\vec{s}}_{i}=\vec{s}_{i} \cdot\left(\vec{\omega}_{10} \times \vec{q}_{i}+\vec{v}\right)=\vec{s}_{i} \cdot \vec{v}-\vec{s}_{i} \cdot\left(\vec{q}_{i} \times \vec{\omega}_{10}\right)=\vec{s}_{i} \cdot \vec{v}-\vec{s}_{i} \cdot S\left(\vec{q}_{i}\right) \vec{\omega}_{10}=J_{i}\left[\begin{array}{l}\vec{v} \\ \vec{\omega}_{10}\end{array}\right]$

W powyższym równaniu przez $J_{i}$ oznaczono i-ty wiersz jakobianu manipulatora

$$
J_{i}=\left[\begin{array}{ll}
\vec{s}_{i} & -\vec{s}_{i} S\left(\vec{q}_{i}\right)
\end{array}\right]
$$

Prędkości wysuwu wszystkich sześciu siłowników można zestawić w sześcioelementowy wektor

$$
\dot{\vec{L}}=\left[\dot{L}_{1}, \dot{L}_{2}, \ldots, \dot{L}_{6}\right]^{T}
$$

Z drugiej strony, korzystając ze wzoru (18), możemy przedstawić prędkość wysuwu i-tego siłownika $\dot{\vec{S}}_{i}$ przy pomocy prędkości kątowej $\vec{W}_{i}$ i-tego siłownika

$\dot{\vec{S}}_{i}=\dot{L}_{i} \vec{s}_{i}+L_{i} \dot{\vec{s}}_{i}=\dot{L}_{i} \vec{s}_{i}+L_{i}\left(\vec{W}_{i} \times \vec{s}_{i}\right)=\dot{L}_{i} \vec{s}_{i}+L_{i} \vec{W}_{i} \times \vec{s}_{i}$.

Biorąc obustronny iloczyn wektorowy powyższego równania względem $\vec{s}_{i}$ i korzystając z faktu, że nie występuje obrót wzdhuż osi siłownika (tzn. $\left.\vec{s}_{i} \cdot \vec{W}_{i}=0\right)$ oraz że $\vec{s}_{i} \cdot \vec{s}_{i}=1$ i $\vec{s}_{i} \times \vec{s}_{i}=0$ otrzymujemy prędkość kątową i-tego siłownika $\vec{W}_{i}$ w postaci

$$
\vec{W}_{i}=\frac{1}{L_{i}} \vec{s}_{i} \times \dot{\vec{S}}_{i}
$$

Przyspieszenie wierzchołka $P_{i}$ jest pochodną względem czasu wektora $\dot{\vec{S}}_{i}$, opisującego prędkość i-tego siłownika, i wyrażone przy pomocy prędkości kątowej $\vec{\omega}_{10}$ i przyspieszenia kątowego $\vec{\varepsilon}_{10}$ ruchomej platformy ma postać

$\ddot{\vec{S}}_{i}=\vec{\varepsilon}_{10} \times \vec{q}_{i}+\vec{\omega}_{10} \times \dot{\vec{q}}_{i}+\dot{\vec{v}}=\vec{\varepsilon}_{10} \times \vec{q}_{i}+\vec{\omega}_{10} \times\left(\vec{\omega}_{10} \times \vec{q}_{i}\right)+\vec{a}$

Powyższe przyspieszenie może być wyrażone przy pomocy prędkości kątowej $\vec{W}_{i}$ i przyspieszenia kątowego $\vec{A}_{i}$ i-tego siłownika

$\ddot{\vec{S}}_{i}=\left(\ddot{L}_{i}-L_{i} \vec{W}_{i} \cdot \vec{W}_{i}\right) \vec{s}_{i}+2 \dot{L}_{i} \vec{W}_{i} \times \vec{s}_{i}+L_{i} \vec{A}_{i} \times \vec{s}_{i}$

Biorąc obustronny iloczyn skalarny powyższego równania względem $\vec{s}_{i}$ i korzystając $\mathrm{z}$ własności iloczynu mieszanego uzyskujemy przyspieszenie wysuwu i-tego siłownika w postaci

$$
\ddot{L}_{i}=\vec{s}_{i} \cdot \ddot{\vec{S}}_{i}+L_{i} \vec{W}_{i} \cdot \vec{W}_{i}
$$

Przyspieszenia wysuwu wszystkich sześciu siłowników można zestawić w sześcioelementowy wektor

$$
\ddot{\vec{L}}=\left[\ddot{L}_{1}, \ddot{L}_{2}, \ldots, \ddot{L}_{6}\right]^{T}
$$


Biorąc obustronny iloczyn wektorowy równania (27) względem $\vec{s}_{i}$ i korzystając z faktu, że $\vec{s}_{i} \cdot \vec{W}_{i}=0$ oraz $\vec{s}_{i} \cdot \vec{A}_{i}=0$ otrzymujemy przyspieszenie kątowe i-tego siłownika w postać

$$
\vec{A}_{i}=\frac{1}{L_{i}}\left(\vec{S}_{i} \times \ddot{\vec{S}}_{i}-2 \dot{L}_{i} \vec{W}\right) .
$$

Powyższe wyrażenia opisują pozycję, prędkość i przyspieszenie i-tego siłownika.

\subsection{Bezwładność i-tego siłownika}

Środek lokalnego układu współrzędnych dla korpusu (dolnej części) i-tego siłownika pokrywa się z wierzchołkiem $B_{i}$. Oś $x_{i}^{(S)}$ pokrywa się z osią siłownika, oś $y_{i}^{(S)}$ jest wzdłuż osi obrotu zablokowanej w przegubie Cardana, a oś $z_{i}^{(S)}$ jest prostopadła do osi $x_{i}^{(S)}$ i $y_{i}^{(S)}$ zgodnie z regułą prawej ręki. Lokalny układ współrzędnych dla tłoczyska (górnej części) itego siłownika ma tą samą orientację co lokalny układ współrzędnych dla korpusu i-tego siłownika, a jego środek pokrywa się z wierzchołkiem $P_{i}$. Geometryczne i kinematyczne parametry i-tego siłownika muszą być przekształcone z lokalnych układów współrzędnych dla korpusu i tłoczyska i-tego siłownika do układu odniesienia dla całego i-tego siłownika.

Przekształcenie z lokalnego układu współrzędnych dla korpusu do układu odniesienia związanego z całym i-tym siłownikiem jest tylko obrotem. Osie $\mathrm{x}, \mathrm{z}, \mathrm{y}$ układu odniesienia maja postać

$$
\begin{array}{ll}
\text { oś x: } \quad x_{i}^{(S)}=\vec{s}_{i}, \\
\text { oś y: } \quad y_{i}^{(S)}=\frac{\vec{k}_{i} \times \vec{s}_{i}}{\left|\vec{k}_{i} \times \vec{s}_{i}\right|}, \\
\text { oś z: } \quad z_{i}^{(S)}=x_{i}^{(S)} \times y_{i}^{(S)} .
\end{array}
$$

Zatem macierz przekształcenia ma postać

$$
T_{i}=\left[x_{i}^{(S)} y_{i}^{(S)} z_{i}^{(S)}\right]
$$

Przekształcenie z lokalnego układu współrzędnych dla tłoczyska do układu odniesienia związanego z całym i-tym siłownikiem jest dane tą samą macierzą obrotu $T_{i}$ z przesunięciem równym długości itego siłownika.

Jeżeli $\vec{r}_{i d 0}$ i $\vec{r}_{i u 0}$ oznaczają wektory położenia środków ciężkości korpusu i tłoczyska i-tego siłownik, to mogą być one następująco zapisane w układzie odniesienia dla całego i-tego siłownika

$$
\begin{gathered}
\vec{r}_{i d}=T_{i} \vec{r}_{i d 0} \\
\vec{r}_{i u}=T_{i}\left(\vec{r}_{i u 0}+\vec{c}_{i}\right)
\end{gathered}
$$

gdzie $\vec{c}_{i}=\left[\begin{array}{lll}L_{i} & 0 & 0\end{array}\right]^{T}$.

Prędkość liniową i przyspieszenie liniowe korpusu i-tego siłownika dane jest wzorami (dla korpusu występuje tylko ruch obrotowy)

$$
\begin{gathered}
\vec{v}_{i d}=\dot{\vec{r}}_{i d}=\vec{W}_{i} \times \vec{r}_{i d} \\
\vec{a}_{i d}=\ddot{\vec{r}}_{i d}=\vec{A}_{i} \times \vec{r}_{i d}+\vec{W}_{i} \times\left(\vec{W}_{i} \times \vec{r}_{i d}\right)
\end{gathered}
$$

$\mathrm{W}$ podobny sposób można zapisać prędkość liniowa i przyspieszenie liniowe tłoczyska i-tego siłownika (dla tłoczyska zachodzi ruch postępowy i obrotowy).

$$
\vec{v}_{i u}=\dot{\vec{r}}_{i u}=\vec{W}_{i} \times \vec{r}_{i u}+\dot{L}_{i} \vec{s}_{i}
$$

$\vec{a}_{i u}=\vec{A}_{i} \times \vec{r}_{i u}+\vec{W}_{i} \times\left(\vec{W}_{i} \times \vec{r}_{i u}\right)+\ddot{L}_{i} \vec{s}_{i}+2 \dot{L}_{i} \vec{W}_{i} \times \vec{s}_{i}$

Moment bezwładności $I_{i d}$ dolnej części i-tego siłownika w ustalonym układzie współrzędnych może być otrzymany z momentu bezwładności $I_{i d 0} \mathrm{z}$ lokalnego układu współrzędnych poprzez przekształcenie

$$
I_{i d}=T_{i} I_{i d 0} T_{i}^{T} .
$$

Moment bezwładności $I_{\text {iu }}$ górnej części i-tego siłownika otrzymujemy korzystając z twierdzenia Steinera dla tensora momentu bezwładności

$I_{i u}=T_{i}\left|I_{i u 0}+m_{i u}\left(\vec{c}^{T} \vec{c} E_{3}-\vec{c} \cdot \vec{c}^{T}\right)\right| T_{i}^{T}=T_{i}\left(I_{i u 0}+m_{i u} L^{2} \operatorname{diag}(0,1,1)\right) T_{i}^{T}$,

$$
\text { gdzie } \quad E_{3}=\left[\begin{array}{lll}
1 & 0 & 0 \\
0 & 1 & 0 \\
0 & 0 & 1
\end{array}\right], \operatorname{diag}(0,1,1)=\left[\begin{array}{lll}
0 & 0 & 0 \\
0 & 1 & 0 \\
0 & 0 & 1
\end{array}\right] \text {. }
$$

\subsection{Równania dynamiki i-tego siłownika}

Rozważmy momenty działające na dolną i górną część siłownika $\mathrm{w}$ ustalonym układzie współrzędnych i-tego siłownika. Równanie Eulera dla i-tego siłownika ma postać

$$
\begin{aligned}
\left(I_{i d}\right. & \left.+I_{i u}\right) \vec{A}_{i}+\vec{W}_{i} \times\left(I_{i d}+I_{i u}\right) \vec{W}_{i}+m_{i d} \vec{r}_{i d} \times \vec{a}_{i d}+m_{i u} \vec{r}_{i u} \times \vec{a}_{i u}= \\
& =\left(m_{i d} \vec{r}_{i d}+m_{i u} \vec{r}_{i u}\right) \times \vec{g}+\vec{S}_{i} \times \vec{F}_{i s}
\end{aligned}
$$

gdzie

$\vec{F}_{i s}$ jest siłą reakcji w przegubie sferycznym działająca na siłownik.

Równania (41) można zapisać w postaci

$$
\vec{S}_{i} \times \vec{F}_{i s}=\vec{f}_{i}
$$

gdzie

$\vec{f}_{i}=\left(I_{i d}+I_{i u}\right) \vec{A}_{i}+\vec{W}_{i} \times\left(I_{i d}+I_{i u}\right) \vec{W}_{i}+m_{i d} \vec{r}_{i d} \times \vec{a}_{i d}+$ $+m_{i u} \vec{r}_{i u} \times \vec{a}_{i u}-\left(m_{i d} \vec{r}_{i d}+m_{i u} \vec{r}_{i u}\right) \times \vec{g}_{i}$

$\mathrm{Z}$ równania (42), poprzez wzięcie iloczynu wektorowego obu stron przez $\vec{s}_{i}$, dostajemy 


$$
\vec{S}_{i} \times\left(\vec{S}_{i} \times \vec{F}_{i s}\right)=\vec{S}_{i} \times \vec{f}_{i}
$$

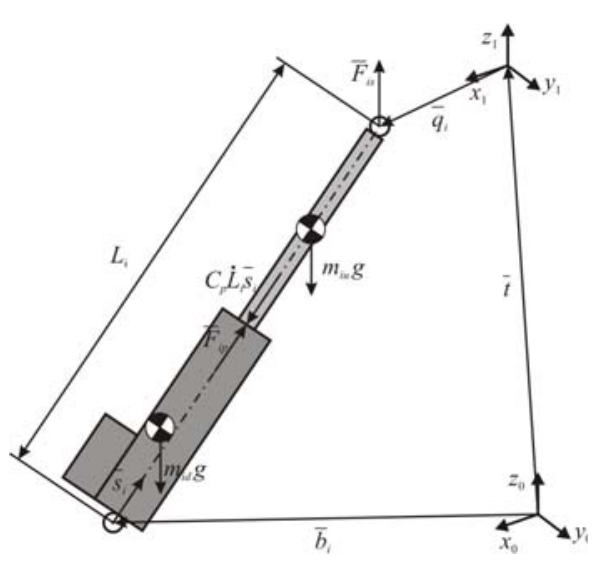

Rys.3. Siły w i-tym siłowniku

Równanie (43) można przekształcić do postaci

$$
\vec{F}_{i s}=x_{i} \vec{s}_{i}-\frac{1}{L}\left(\vec{s}_{i} \times \vec{f}_{i}\right)=x_{i} \vec{s}_{i}-\vec{K}_{i}
$$

gdzie

$$
x_{i}=\vec{s}_{i} \cdot \vec{F}_{i s}
$$

jest składową siły $\vec{F}_{i s}$ w przegubie sferycznym wzdłuż osi siłownika oraz wektor $\vec{K}_{i}=\frac{1}{L}\left(\vec{s}_{i} \times \vec{f}_{i}\right)$ jest znany. Równanie (44) przedstawia siłę $\vec{F}_{i s}$ zależną od jednej niewiadomej $x_{i}$ i wynika z oddziaływania siłownika na ruchomą platformę.

Rozważając równanie Newtona dla górnej części siłownika (rys.3.) dostajemy

$$
-m_{i u} \vec{a}_{i u}+m_{i u} \vec{g}-\vec{F}_{i p}-\vec{F}_{i s}+C_{i p} \dot{L}_{i} \vec{s}_{i}=0
$$

gdzie

$C_{i p} \dot{L}_{i} \vec{s}_{i}$ jest siłą tarcia wiskotycznego w przegubie pryzmatycznym.

W celu wyznaczenia osiowej składowej siły $\vec{F}_{i p}$, która jest siłą wprawiania w ruch siłownika, weźmy iloczyn skalarny równania (46) względem $\vec{s}_{i}$. Wówczas otrzymamy

$$
\vec{s}_{i} \cdot \vec{F}_{i p}=m_{i u} \vec{s}_{i} \cdot\left(\vec{g}-\vec{a}_{i u}\right)+C_{i p} \dot{L}_{i}-\vec{s}_{i} \cdot \vec{F}_{i s} .
$$

Podstawiając (45) do równania (47) uzyskujemy

$$
F_{i}=D_{i}-x_{i}
$$

gdzie

$F_{i}$ jest wartością siły oddziaływania siłownika na ruchomą platformę,

$$
D_{i}=m_{i u} \vec{s}_{i} \cdot\left(\vec{g}-\vec{a}_{i u}\right)+C_{i p} \dot{L}_{i} .
$$

Równanie (48) przedstawia siłę $F_{i}$ zależną od niewiadomej $x_{i}$ dla i-tego siłownika. Sześć niewiadomych $x_{i}$ może być ustalonych $\mathrm{z}$ równania ruchu dla ruchomej platformy.

\section{Kinematyka i dynamika ruchomej platformy.}

\subsection{Przyspieszenie i bezwladność ruchomej plat- formy.}

Jeżeli $\vec{R}_{0}$ jest wektorem opisującym położenie środka ciężkości platformy $\mathrm{w}$ ruchomym układzie współrzędnych, to ten sam wektor w globalnym układzie współrzędnych ma postać

$$
\vec{h}=\vec{r}+\vec{t}=R_{0}^{1} \vec{r}^{(1)}+\vec{t} .
$$

Stąd prędkości i przyspieszenie w środku ciężkości ruchomej platformy ma postać

$$
\begin{gathered}
\vec{v}=\dot{\vec{h}}=\vec{\omega} \times \vec{r}+\dot{\vec{t}}, \\
\vec{a}=\ddot{\vec{h}}=\vec{\varepsilon} \times \vec{r}+\vec{\omega} \times(\vec{\omega} \times \vec{r})+\ddot{\vec{t}} .
\end{gathered}
$$

Moment bezwładności $I_{p}$ ruchomej platformy (łącznie z obciążeniem) może być przekształcony do postaci we współrzędnych globalnych poprzez

$$
I=R_{0}^{1} I_{d}\left(R_{0}^{1}\right)^{T} .
$$

\subsection{Równania dynamiki ruchomej platformy.}

Załóżmy, że zewnętrzne obciążenie działające na platformę (o ile istnieje) jest wyrażone w lokalnym układzie współrzędnych platformy i oznaczone symbolami $\vec{F}_{e x t}$ - siły zewnętrzne, $\vec{M}_{e x t}$ - moment zewnętrzne.

Wówczas równanie Newtona dla platformy ma postać

$$
-M \vec{a}+M \vec{g}+R_{0}^{1} \vec{F}_{e x t}-\sum_{i=1}^{6} \vec{F}_{i s}=0 .
$$

Podstawiając równanie (44) otrzymujemy

$$
\sum_{i=1}^{6} x_{i} \vec{s}_{i}=R_{o}^{1} \vec{F}_{e x t}+M(\vec{g}-\vec{a})+\sum_{i=1}^{6} \vec{K}_{i} .
$$

Rozważając równanie Eulera względem początku lokalnego układu współrzędnych otrzymujemy

$$
\begin{aligned}
& -M \vec{r} \times \vec{a}+M r \times \vec{g}-I \vec{\varepsilon}-\vec{\omega} \times(I \vec{\omega})+R_{0}^{1} M_{e x t}- \\
& -\sum_{i=0}^{6}\left(\vec{q}_{i} \times \vec{F}_{i s}\right)+\sum_{i=0}^{6} C_{i s}\left(\vec{W}_{i}-\vec{\omega}\right)=0
\end{aligned}
$$

Podstawiając ponownie równanie (44) dostajemy

$\sum_{i=0}^{6}\left(x_{i} \vec{q}_{i} \times \vec{s}_{i}\right)=M \vec{r} \times(\vec{g}-\vec{a})-I \vec{\varepsilon}-\vec{\omega} \times(I \vec{\omega})+R_{0}^{1} M_{e x t}+$

$+\sum_{i=0}^{6}\left[\vec{q}_{i} \times \vec{K}_{i}+C_{i s}\left(\vec{W}_{i}-\vec{\omega}\right)\right]=0$

Równania (54) i (56) dają sześć równań z sześcioma niewiadomymi $x_{1}, x_{2}, \ldots, x_{6}$. Scalając je dostajemy 


$$
\begin{aligned}
& {\left[\begin{array}{cccc}
\vec{s}_{1} & \vec{s}_{1} & \ldots & \bar{s}_{6} \\
\vec{q}_{1} \times \vec{s}_{1} & \vec{q}_{2} \times \vec{s}_{2} & \ldots & \vec{q}_{6} \times \vec{s}_{6}
\end{array}\right] \cdot\left[\begin{array}{c}
x_{1} \\
x_{2} \\
\vdots \\
x_{6}
\end{array}\right]=} \\
& =\left[\begin{array}{c}
R_{0}^{1} \vec{F}_{e x t}+M(\vec{g}-\vec{a})+\sum_{i=0}^{6} \vec{K}_{i} \\
M \vec{r} \times(\vec{g}-\vec{a})-I \vec{\varepsilon}-\vec{\omega} \times(I \vec{\omega})+R_{0}^{1} M_{e x t}+\sum_{i=1}^{6}\left(\vec{q}_{i} \times \vec{K}_{i}+C_{i s}\left(\vec{W}_{i}-\vec{\omega}\right)\right)
\end{array}\right]
\end{aligned}
$$

lub

$$
H \vec{x}=\vec{d}
$$

gdzie

$$
\begin{gathered}
H=\left[\begin{array}{cccc}
\vec{s}_{1} & \vec{s}_{1} & \cdots & \vec{s}_{6} \\
\vec{q}_{1} \times \vec{s}_{1} & \vec{q}_{2} \times \vec{s}_{2} & \cdots & \vec{q}_{6} \times \vec{s}_{6}
\end{array}\right] \\
\vec{x}=\left[\begin{array}{llll}
x_{1} & x_{2} & \cdots & x_{6}
\end{array}\right]^{T} \\
\vec{d}=\left[\begin{array}{c}
R_{0}^{1} \vec{F}_{e x t}+M(\vec{g}-\vec{a})+\sum_{i=0}^{6} \vec{K}_{i} \\
M \vec{r} \times(\vec{g}-\vec{a})-I \vec{\varepsilon}-\vec{\omega} \times(I \vec{\omega})+R_{0}^{1} M_{e x t}+\sum_{i=1}^{6}\left(\vec{q}_{i} \times \vec{K}_{i}+C_{i s}\left(\vec{W}_{i}-\vec{\omega}\right)\right)
\end{array}\right]
\end{gathered}
$$

Rozwiązując układ równań (53) można wyznaczyć wartości wektora $\vec{x}$. Znając wektor $\vec{x}$ można obliczyć wartości sił wewnętrznych w siłownikach ze wzoru (48).

\section{Wykonanie platformy Stewarta-Gougha oraz koncepcja sterowania}

Do budowy manipulatora w zmniejszonej skali wykorzystano siłowniki elektryczne. Wybrano je, ponieważ charakteryzują się dużą szybkość działania oraz brakiem konieczności zapewnienia zasilania olejem hydraulicznym lub sprężonym powietrzem, jak to ma miejsc w przypadku siłowników hydraulicznych lub pneumatycznych. Słowniki połączone są za pośrednictwem przegubów kardana z ruchomą płytą górna. Przeguby kardana zostały zastosowane również $\mathrm{w}$ przypadku połączenia $\mathrm{z}$ nieruchomą płytą dolną, jednak dodatkowo zastosowano adaptery, które są elementem pośrednim. Płyty wykonane zostały $\mathrm{z}$ aluminium, ze względu na niewielką masę oraz możliwość łatwej modyfikacji położenia siłowników poprzez nawiercenie dodatkowych otworów. Możliwość ta została zabezpieczona w celu ewentualnej konieczności modyfikacji geometrii platformy. $\mathrm{Na}$ obu końcach siłowników zostały zastosowane przeguby blokujące obrót, ponieważ tłoczyska zastosowanych siłowników nie są wyposażone w zabezpieczenia przed obrotem. W celu umożliwienia precyzyjnego sterowania siłownikami, każdy z nich został wyposażony w zblokowany $\mathrm{z}$ silnikiem encoder oraz hamulec. Dodatkowo na korpusie silnika umieszczone zostały wyłączniki krańcowe. Wygląd zmontowanej platformy przedstawiono na rys. 4.

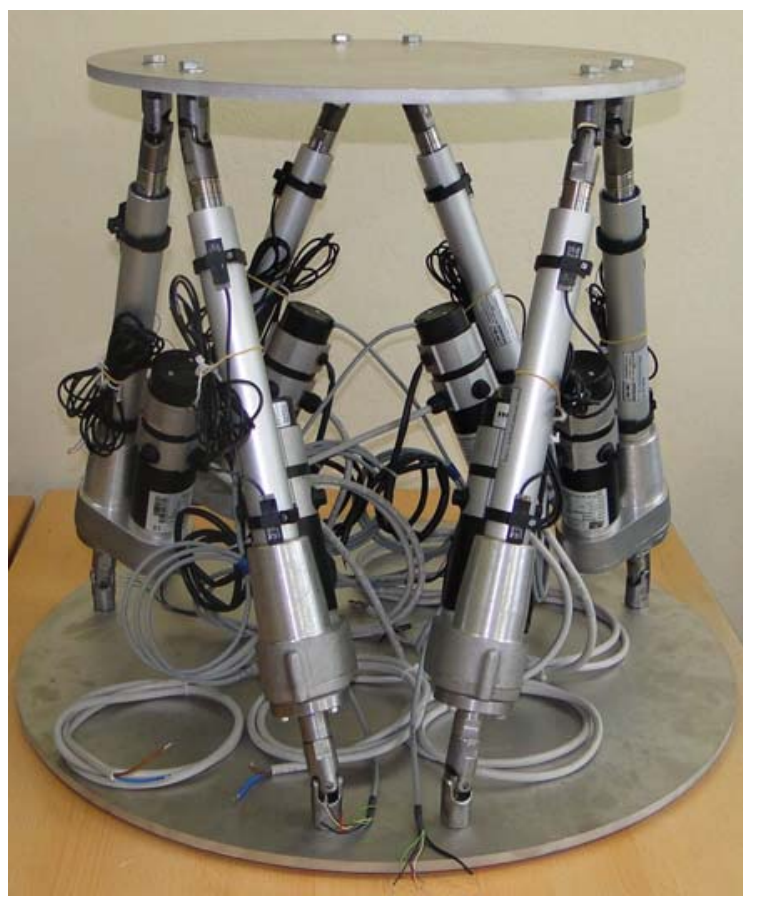

Rys.4. Platforma Stewarta-Gougha wyposażona w siłowniki elektryczne

W torze sterowania wykorzystane zostały sterowniki silników prądu stałego typu SDC106 firmy Wobit (rys. 5). W celu uruchomienia silnika należy przesłać do sterownika dwa sygnały cyfrowe, jeden inicjujący rozruch siłownika, a drugi określający kierunek ruchu oraz sygnał analogowy określający prędkość ruchu. Informacje o wykonanym wysuwie odczytywane są $\mathrm{z}$ encodera, a $\mathrm{w}$ razie osiagnięcia maksymalnego lub minimalnego wysuwu siłownik jest zatrzymywany za pośrednictwem wyłącznika krańcowego. Encodery nie zapewniaja jednak bezpośredniej informacji o ruchach górnej płyty, dlatego też na górnej płycie zamontowany zostanie 3-osiowy akcelerometr oraz 2-osiowy inklinometr.

Wszystkie sygnały sterujące siłownikami oraz zwrotne odczytywane $z$ enkoderów oraz akcelerometru i inklinometru wysyłane lub zbierane będą za pomocą kart wejść/wyjść zamontowanych na slotach PCI dwóch komputerów klasy PC. Karty odpowiedzialne za ruchy siłowników zamontowane będą w komputerze zwanym ,target”. Będzie to karta wyjść analogowych PD2-AO-8/16 firmy United Electronic Industries, karta wejść i wyjść cyfrowych PCI-DIO96 firmy Measurement Computing oraz dwie karty wejść encoderowych typu PCI-QUAD04 firmy Measurement Computing. Natomiast karta wejść analogowych PCI-DAS6040 firmy Measurement Computing, rejestrująca informacje $\mathrm{z}$ czujników zamontowanych na górnej ruchomej płycie platformy umieszczona zostanie $\mathrm{w}$ głównym komputerze symulatora zwanym ,host”. Wspomniane karty obsługiwać będą następującą liczbę wejść i wyjść:

- 12 wyjść cyfrowych do zainicjowania oraz określenia kierunku ruchu siłownika, 
- 6 wyjść analogowych do określenia prędkości ruchu siłownika,

- 6 wyjść cyfrowych do sterowania hamulcami silników elektrycznych,

- 6 cyfrowych kanałów enkoderów,

- 12 wejść cyfrowych do wyłączników krańcowych,

- 5 wejść analogowych do rejestracji sygnałów z akcelerometru oraz inklinometru.

Główny komputer symulatora (,host”) pracował będzie pod kontrolą systemu Microsoft Windows, natomiast komputer sterujący platformą (,target”) musi pracować pod kontrolą systemu czasu rzeczywistego. Założenie to $\mathrm{w}$ przypadku opisywanego symulatora zrealizowane zostanie przy wykorzystaniu środowiska Matlab Simulink wraz z przybornikiem xPC Target. Przybornik ten umożliwia uruchomienie opracowanego programu sterującego $\mathrm{w}$ czasie rzeczywistym, pod kontrolą systemu czasu rzeczywistego, uruchamianego $\mathrm{z}$ dyskietki lub płyty $\mathrm{CD}$. W związku z tym do obsługi ruchów manipulatora, wybrano karty, które obsługiwane są przez wspomniany przybornik. Natomiast karta odpowiedzialna z rejestrację sygnałów z czujników, która nie jest obsługiwana przez przybornik xPC Target, umieszczona zostanie w głównym komputerze symulatora („host”).
Wybrane rozwiązanie wymaga zastosowania synchronizacji pomiaru realizowanego przez kartę oraz synchronizacji współpracy obu komputerów. W związku z tym poprzez przybornik xPC Target oraz kartę wyjść cyfrowych zainstalowaną w komputerze „target” generowany będzie impuls wyzwalający rejestrowany za pośrednictwem karty wejść analogowych zainstalowana na komputerze „host”. W ten sposób zapewniona zostanie synchronizacja pomiaru realizowanego przez kartę, a także wytwarzany będzie sygnał synchronizujący dla komputera obliczającego model pociagu, co umożliwi jego realizację w środowisku Microsoft Windows.

Artykuł powstał $\mathrm{w}$ ramach projektu badawczego „Symulator jazdy pojazdów szynowych do optymalizacji zużycia energii podczas ruchu pociagów, projektowania nowych tras kolejowych oraz szkolenia maszynistów" N N509 501338 finansowanego przez Ministerstwo Nauki i Szkolnictwa Wyższego. 